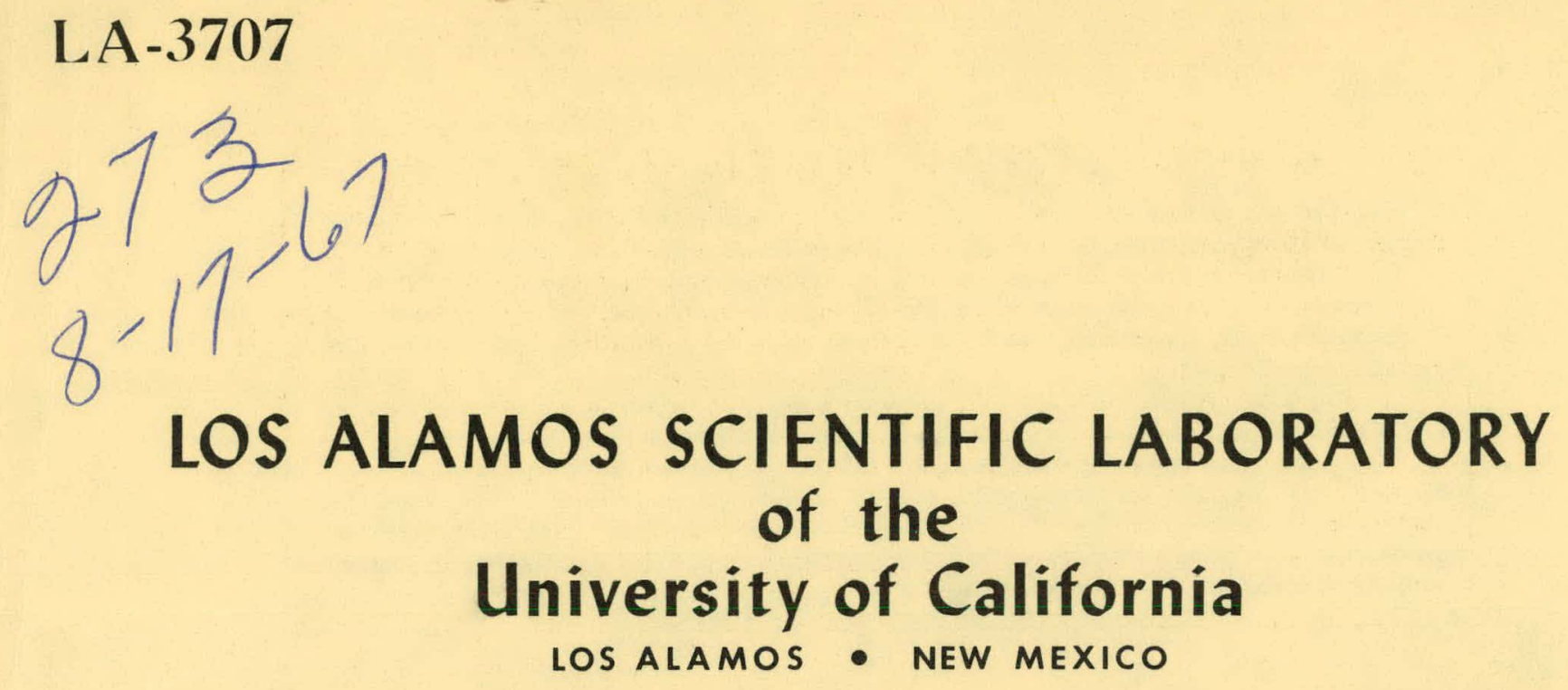

\begin{abstract}
Fabrication of Ceramic Components for Use in Plutonium Electrorefining
\end{abstract}




\section{DISCLAIMER}

This report was prepared as an account of work sponsored by an agency of the United States Government. Neither the United States Government nor any agency Thereof, nor any of their employees, makes any warranty, express or implied, or assumes any legal liability or responsibility for the accuracy, completeness, or usefulness of any information, apparatus, product, or process disclosed, or represents that its use would not infringe privately owned rights. Reference herein to any specific commercial product, process, or service by trade name, trademark, manufacturer, or otherwise does not necessarily constitute or imply its endorsement, recommendation, or favoring by the United States Government or any agency thereof. The views and opinions of authors expressed herein do not necessarily state or reflect those of the United States Government or any agency thereof. 


\section{DISCLAIMER}

Portions of this document may be illegible in electronic image products. Images are produced from the best available original document. 
This report was prepared as an account of Government sponsored work. Neither the United States, nor the Commission, nor any person acting on behalf of the Commission:

A. Makes any warranty or representation, expressed or implied, with respect to the accuracy, completeness, or usefulness of the information contained in this report, or that the use of any information, apparatus, method, or process disclosed in this report may not infringe privately owned rights; or

B. Assumes any liabilities with respect to the use of, or for damages resulting from the use of any information, apparatus, method, or process disclosed in this report.

As used in the above, "person acting on behalf of the Commission" includes any employee or contractor of the Commission, or employee of such contractor, to the extent that such employee or contractor of the Commission, or employee of such contractor prepares, disseminates, or provides access to, any information pursuant to his employment or contract with the Commission, or his employment with such contractor.

This report expresses the opinions of the author or authors and does not necessarily reflect the opinions or views of the Los Alamos Scientific Laboratory.

Printed in the United States of America. Available from Clearinghouse for Federal Scientific and Technical Information National Bureau of Standards, U. S. Department of Commerce

Springfield, Virginia 22151

Price: Printed Copy $\$ 3.00$; Microfiche $\$ 0.65$ 


\section{LOS ALAMOS SCIENTIFIC LABORATORY of the University of California los alamos - NEW MEXICO}

Report written: March 1, 1967

Report distributed: August 1, 1967

\section{Fabrication of Ceramic Components for Use in Plutonium Electrorefining}

by

S. D. Stoddard

D. E. Nuckolls

\section{LEGAL NOTICE}

This report was prepared as an account of Government sponsored work. Neither the United States, nor the Commission, nor any person acting on behalf of the Commission:

A. Makes any warranty or representation, expressed or implied, with respect to the accuracy, completeness, or usefulness of the information contained in this report, or that the use of any information, apparatus, method, or process disclosed in this report may not infringe privately owned rights; or

D. Assumes any liabuities with respect to the use of, or for damages resulting from the use of any information, apparatus, method, or process disclosed in this report.

As used in the above, "person acting on behalf of the Commission" includes any employee or contractor of the Commission, or employee of such contractor, to the extent that such employee or contractor of the Commission, or employee of such contractor prepares, disseminates, or provides access to, any information pursuant to his employment or contract with the Commission, or his employment with such contractor. 
THIS PAGE

WAS INTENTIONALLY

LEFT BLANK 


\title{
FABRICATION OF CERAMIC COMPONEINTS FOR USE IN PLUTONIUM ELECTROREFINING
}

by

\author{
S. D. Stoddard and D. E. Nuckolls
}

ABSTRACT

\begin{abstract}
A method of fabricating ceramic cells and associated components for use in the electrolytic refining or electrowinning of plutonium metal is described. Details for making such ware of impervious alumina and magnesia are described. References on the development of processes for the electrochemical preparation of up to $3.5 \mathrm{~kg}$ per batch of plutonium and the ceramics required for such processes are also given.
\end{abstract}

\section{INTRODUCTTON}

Although the electrochemical preparation of $\mathrm{Pu}$ metal was reported over 20 years ago by Kolodney ${ }^{1}$ of this Laboratory, the feasibility of a process for producing the metal in relatively large quantities was not reported until 1958 by Leary et al. ${ }^{2,3}$ Batch processes for production of up to $3.5 \mathrm{~kg}$ of metal were reported by Mullins, Leary, Morgan, and Maraman ${ }^{4,5}$ in the open literature in 1963. Subsequent reports have dealt with improved processes and purities attained therein. $6,7,8$

During some of this period, workers at Hanford Atomic Products Laboratory (HAPO), 9 Argonne National Laboratory, ${ }^{10}$ and the Dow Chemical Company at Rocky Flats ${ }^{11}$ have also reported electrochemical processing of Pu. The melt container and associated components have evolved from metals, namely $\mathrm{Ta}$, to ceramics, the fabrication of which is the subject of this paper.

The fabrication of ceramic components for the HAPO electrowinning and batch electrorefining process wherein the ceramic body is composed of 4 mole \% $\mathrm{Mg}_{2} \mathrm{THO}_{4}$ and 96 mole \% $\mathrm{MgO}$ has been described by Rosenfels. ${ }^{12}$ Work with magnesia components at the
Dow Chemical Rocky Flats Plant has been reported by Kessel et al. 13

At this Laboratory the first ceramic cells were made of aluminum oxide ceramics utilizing metallic Ta stirrers. The alumina cells were found satisfactory in all-chloride electrolytes. It was seen that by substituting $\mathrm{MgO}$ for $\mathrm{Al}_{2} \mathrm{O}_{3}$, the impurity content of the product metal could be cut from 40 $\mathrm{ppm}$ of $\mathrm{Al}$ to less than $5 \mathrm{ppm}$ of $\mathrm{Mg}$. Incidental to the lowering of the total impurity content by this substitution, it was found that $\mathrm{PuF}_{3}$ or $\mathrm{PuF}_{4}$ could be used in place of the uncommon and hygroscopic $\mathrm{PuCl}_{3}$ electrolyte. Mixed fluoride-chloride electrolytes were found unsatisfactory when alumina cells were used because the $\mathrm{Al}$ concentration of the $\mathrm{Pu}$ increased from 40 to $450 \mathrm{ppm}$. Consequently, all ceramic components, i.e., anode container, electroIyte container, stirrer, and protective anode sheath, were thenceforth slip cast of impervious magnesia $\left(\mathrm{MgO}+3\right.$ wt $\left.\% \mathrm{Y}_{2} \mathrm{O}_{3}\right)$.

Figure 1 1llustrates various ceramic components produced at IASL for use in refining processes. 


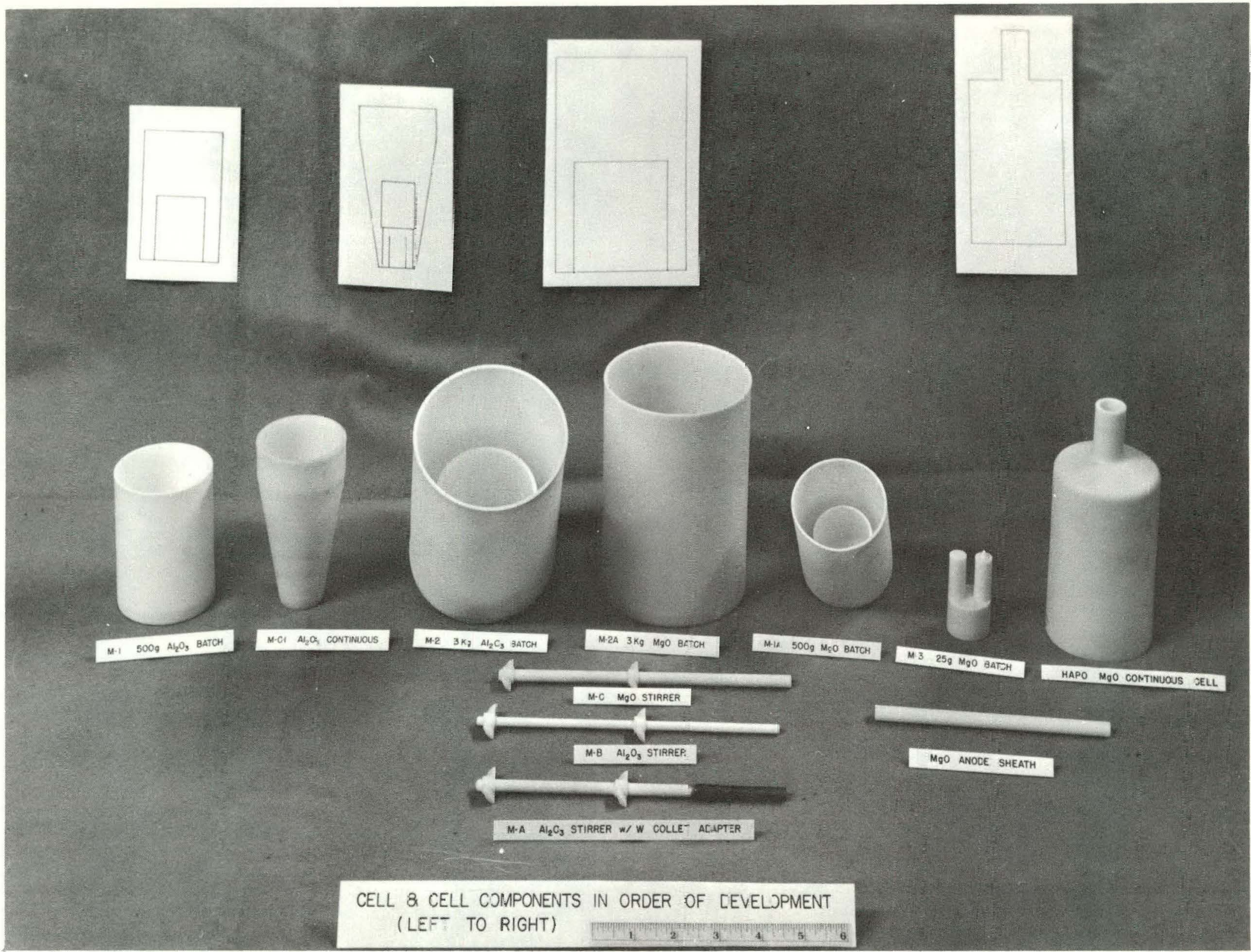

Fig. 1. IASL produced ceramic components Zor refinir-s processek. 
2. MATERTALS

\section{Properties Required}

Ceramic accessories for electrorefining Pu metal must have the following properties.

1. The cell must contain the low viscosity melt ( $\mathrm{NaCl}, \mathrm{KCl},+2$ mole $\% \mathrm{PuCl}_{3}, \mathrm{PuF}_{3}$, or $\mathrm{PuF}_{4}$ ) employed at temperatures up to approximately $850^{\circ} \mathrm{C}$.

2. The cell and components should have high thermodynamic stability to minimize the possibility of reaction between the container and the molten salts or molten $\mathrm{Pu}$, or both.

3. The cell and components must have adequate thermal shock resistance. The cells are heated at $50^{\circ} \mathrm{C} / \mathrm{h}$ to $740^{\circ} \mathrm{C}$ and held $\mathrm{I} \mathrm{h}$ at temperature before the temperature is raised to $840^{\circ} \mathrm{C}$ after which they are furnace cooled.

4. The material must be mechanically strong to withstand thermal and mechanical shock. The stirrer revolves at up to $1000 \mathrm{rpm}$, imposing high tensile stresses, even though it revolves in a low viscosity medium.

5. The cells and components should be commercially available, fabricable by established techniques, and reasonably inexpensive. Although the cell is for one-time use, the stirrers and anode sheaths are used repeatedly. An average of seven cycles is realized with the stirrers, and 10 to 12 cycles with the anode rod sheaths.

Figure 2 illustrates the latest electrorefining process assembly, predecessors of which are completeIy described elsewhere. ${ }^{14}$ Figure 3 shows the ceramic components in greater detail.

The choices of container materials for the molten eleclrulytes and molten $\mathrm{Pu}$ are rather limited. Both corrosion resistance and corrosion products are of consideration in the selection; i.e., Al cannot be easily removed from the product metal where $\mathrm{Mg}$ is easily removed by vacuum melting. From a consideration of their free energies of formation, the fol1 nwing oxides could be used in order of increasing stability $\left(-\triangle \mathrm{F}, \mathrm{K}\right.$ cal $/ \mathrm{g}$-atom oxygen at $\left.1000^{\circ} \mathrm{K}\right)$ : $\mathrm{SiO}_{2}$ (84), $\mathrm{Al}_{2} \mathrm{O}_{3}$ (109), $\mathrm{Pu}_{2} \mathrm{O}_{3}$ (109), $\mathrm{MgO}$ (119), $\mathrm{Y}_{2} \mathrm{O}_{3}$ (119), $\mathrm{ThO}_{2}$ (124), and $\mathrm{CaO}$ (127). Owing to their availability within this Iaboratory, ${ }^{15,16}$ first $\mathrm{Al}_{2} \mathrm{O}_{3}$ and then $\mathrm{MgO}$ were enlisted. Although technology is available for the production of impervious $\mathrm{Y}_{2} \mathrm{O}_{3}$ ware and $\mathrm{CaO}$ ware, ${ }^{17}$ cells have not heen

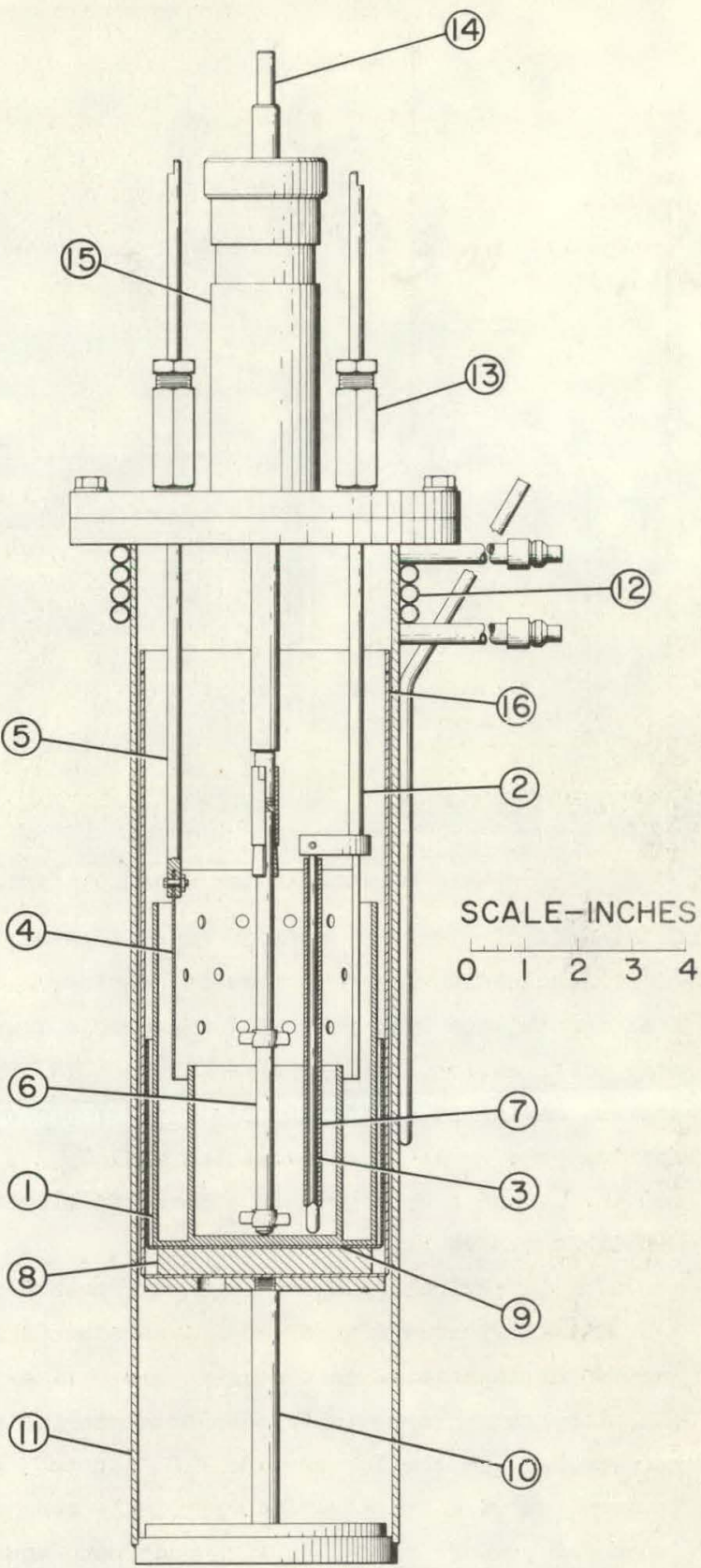

Fig. 2. Electrorefining process assembly.

1. Alumina or magnesia cell

2. Nickel anode lead

3. Tungsten anode rod

4. Tungsten rathode tube

5. Tantalum cathode lead

6. Alumina or magnesia stirrer assembly

7. Magnesia anode sheall

8. Magnesia disc 4-1/8-in. diam $\times 3 / 8-i n$. thick

9. Tantalum safety crucible

10. Stainless steel pedestal

11. Stainless steel tube

12. Copper cooling coils

13. Teflon lined electrode seals

14. Stainless steel stirring shaft

15. Stirrer gland

16. Stainless steel can 


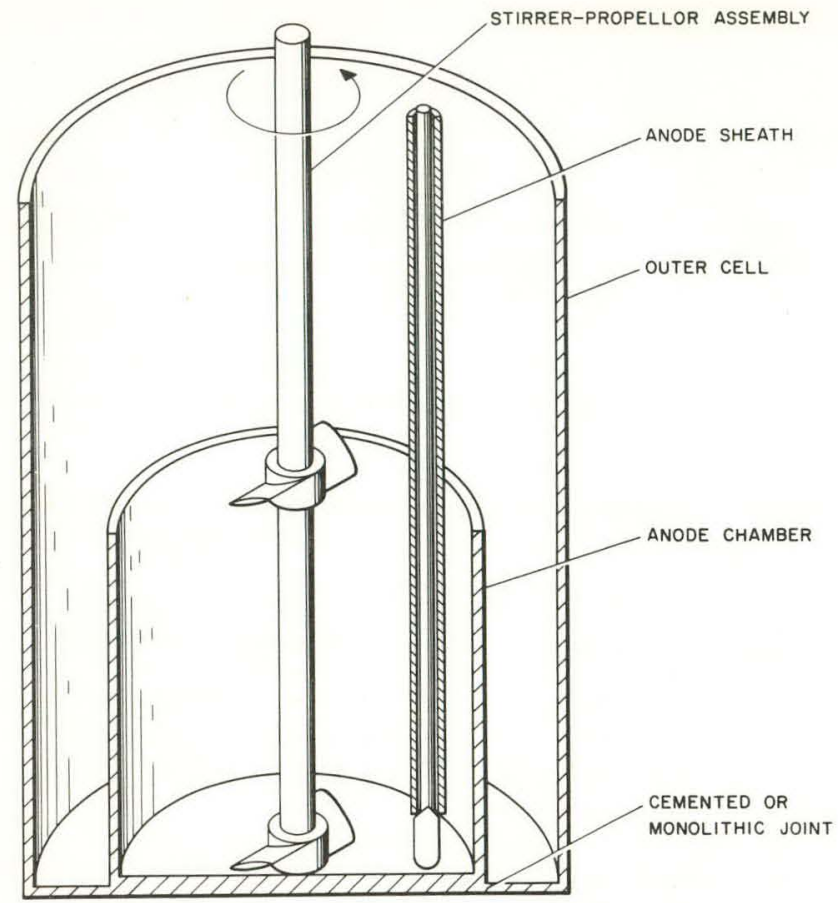

Fig. 3. Ceramic components for electrorefining.

fabricated of either material. $\mathrm{Ia}_{2} \mathrm{O}_{3}$ together with the referenced series of oxides is considered a good possibility with respect to favorable free energy of formation, but it, like the CaO, is hygroscopic, making it difficult to store for production applications. HAPO also evaluated $\mathrm{MgAl}_{2} \mathrm{O}_{4}, \mathrm{Al}_{2} \mathrm{O}_{3}$, $\mathrm{BeO}, \mathrm{ZrO}_{2}$, and porous $\mathrm{MgO}$, as applied to electrowinning, with varying results. ${ }^{18}$

The impervinus $\mathrm{AI}_{2} \mathrm{O}_{3}$ and $\mathrm{MgO}$ ware tested at LASL was fabricated with no additives other than incidental impurities in the as-received material and with grain-growth inhibitors or sintering aids such as $\mathrm{MgO}$ (in the former) and $\mathrm{Y}_{2} \mathrm{O}_{3}$ (up to 3 wt $\%$ ) in each. A wide variety of commercially available fused MgO powders were evaluated and found equally satisfactory in resistance to corrosion. It is interesting that cells made of fused raw material containing as much as 1000 ppm B did not contribute measurable $B(<0.5 \mathrm{ppm})$ to the refined metal.

\section{FABRICATION PROCEDURES}

A. $\mathrm{MgO}-\mathrm{Y}_{2} \mathrm{O}_{3}$ Preparation - General

The starting material used in this process is fused MgO containing less than $1 \%$ total impurities, the major contaminants being $\mathrm{CaO}$ and $\mathrm{SiO}_{2}$. The particle size distribution is $100 \%-200$ mesh, $40 \%+325$ mesh, and $60 \%-325$ mesh. This material is reduced in particle size by ball milling for $42 \mathrm{~h}$ at $55 \mathrm{rpm}$ and $l^{\circ} \mathrm{C}$. A l-gal mill charge includes $2000 \mathrm{~g}$ of $\mathrm{MgO}, 600 \mathrm{ml}$ of water, $3185 \mathrm{~g}$ of l-in.-diam balls, and $1015 \mathrm{~g}$ of 3/4-in.-diam balls. High density alumina balls are used in porcelain mills. Chem1cal analyses of the milled MgO revealed that only about $50 \mathrm{ppm}$ Al were picked up during milling.

After this initial milling, 500 additional $\mathrm{g}$ of the MgO are added together with $3 \%$ by weight of 99.9\% pure, -325 mesh $\mathrm{Y}_{2} \mathrm{O}_{3}$, and the milling is continued for $2 \mathrm{~h}$. The extra $\mathrm{MgO}$ is added to achieve the desired grain size distribution to minimize firing shrinkage. Andreason pipette data indicated that the average particle size was approximately $2 \mu$ although it was not certain that the suspensions were completely deagglomerated.

After being milled for $44 \mathrm{~h}$ the slip is deflocculated through the addition of Formamide* ( $1 \mathrm{ml}$ per $100 \mathrm{~g}$ of $\mathrm{slip})$. The viscosity of the slip is approximately $100 \mathrm{cP}$ as measured with a Brookfield Syncro-Flectric Viscometer Model RVT at $10 \mathrm{rpm}$ using a No. I spindle. The pH of the slip is between 10 and 11 , thereby contributing to long mold life.

The mechanism of deflocculation of this slip is not fully understood. It is suspected that a controlled amount of hydration is necessary to produce a slip having optimum viscosity. The weight loss of samples upon firing indicates that approxImately $16 \% \mathrm{Mg}(\mathrm{OH})_{2}$ is present in the cast ware.

The casting operation is carried out in conventional plaster molds made from three parts water and four parts plaster. The rate of casting is relatively slow; approximately $15 \mathrm{~min}$ are required to form a $1 / 16-1$..- thick wall. The casting rate decreases appreciably as the wall thickness increases beyond $1 / 16$ in. As a consequence it is often difficult to cast thick-walled or solid pieces. Another problem sometimes encountered is caused by the gradual rise of temperature of the slip during casting. The rate of hydroxide formation increases as the slip warms, and the $30 \%$ volume expansion accompanying the reaction may cause the casting to expand in the mold. This problem is not serious except when very thick sections are

*A product of Matheson, Norwood, and Bell, Norwood, Ohio. 
being cast. In this case it is advantageous to cast in chilled molds, thereby reducing the rate at which the slip warms. The slip is kept chilled (approximately $20^{\circ} \mathrm{C}$ ) between casts.

The slip has excellent drain characteristics permitting sharp interior corners to be formed. The drying shrinkage of the cast ware is very low, and it is thus advisable to incorporate a slight taper into one-piece molds. The pieces release from the mold quite easily, and no mold release agent is needed.

The cast pieces are dried at about $35^{\circ} \mathrm{C}$. They may then be stored in the open alr for indefinite periods before firing.

B. $\mathrm{Al}_{2} \mathrm{O}_{3}$ Preparation - General

The starting material used in this process is fused $\mathrm{Al}_{2} \mathrm{O}_{3}$ containing less than $0.2 \%$ total impurities, the major contaminants being $\mathrm{Si}, \mathrm{Fe}, \mathrm{Cr}$, and $\mathrm{Zn}$. The average particle size is $1.7 \mu$ measured with a Fisher Subsieve analyzer. This material is reduced in particle size by ball milling for $30 \mathrm{~h}$ at $55^{\circ} \mathrm{C}$. A l-gal mill charge includes $2000 \mathrm{~g}$ of fused $\mathrm{Al}_{2} \mathrm{O}_{3}, 3.29 \mathrm{~g}$ Marex* deflocculant, $2.64 \mathrm{~g}$ dry sodium meta-silicate, $3185 \mathrm{~g}$ of l-in.-diam balls and $1015 \mathrm{~g}$ of 3/4-in.-diam balls. High density $\mathrm{Al}_{2} \mathrm{O}_{3}$ balls are used in porcelain mills. After $28 \mathrm{~h}$ of milling, $40 \mathrm{~g}$ ( 2 wt $\%$ ) of $\mathrm{Y}_{2} \mathrm{O}_{3}$ is added and milling is continued $2 \mathrm{hr}$ for a total milling time of $30 \mathrm{~h}$. After the slip is discharged from the mill, approximately $7 \mathrm{ml}$ Darvan No. $7^{* *}$ together with $1 \mathrm{ml}$ formaldehyde is added to the batch. The formaldehyde is used to prolong the shelf life of the slip, while the Darvan acts as a deflocculant. The visensity of the slip at this stage in $250 \mathrm{cP}$ an measured with a Brookfield Syncro-Electric Viscometer Model RVT at $10 \mathrm{rpm}$ using a No. 1 spindle. The $\mathrm{pH}$ of the slip is between 8 and 9 , thereby contributing to long mold life.

The casting operation is carried out in the same manner as that employed for the magnesium oxide except that there is no need to chill the moli, The casting rate is essontially identical to that for the magnesia.

\footnotetext{
* Marex, an ammonium alginate from Kelco Company. * Darvan No. 7 , a polyelectrolyte from

R. T. Vanderbilt, Inc.
}

\section{Fabrication Details}

1. MgO-2 wt $\% \mathrm{Y}_{2} \mathrm{O}_{3}$ Cells (LASL Dwg. No. 26Y72325-8, Rev. A, Part 75*).

The outer cell and the anode chamber are cast separately in conventional plaster molds and after removal from the mold are dried separately as decribed above. They are then nested together and fired on prefired, coarse-mix (21-1), dry-pressed MgO setter plates from which they are separated by a 1/16-in.-thick layer of fused $-20+50$ mesh (U.S. Standard series) MgO grain. This setting is fired In natural gas-air fueled kilns to $1775^{\circ} \mathrm{C}$ and held at peak temperature for 20 to $24 \mathrm{~h}$.

During the firing of pieces prepared by this method it is important to use a low heating rate until all of the $\mathrm{Mg}(\mathrm{OH})_{2}$ has been decomposed. This treatment yields relatively translucent ware which has no open porosity, exhibits approximately $11 \%$ firing shrinkage, and has a density ranging from 94 to $97 \%$ of theoretical density.

It is felt that the $\mathrm{Y}_{2} \mathrm{O}_{3}$ addition and the long soak at this relatively high temperature are responsible for the successful bond achieved between the cells.

2. $\mathrm{Al}_{2} \mathrm{O}_{3} \mathrm{Cells}$ (LASL Dwg. No. $26 \mathrm{Y}-72325-8$, Rev. A, Part 75).

The $\mathrm{Al}_{2} \mathrm{O}_{3}$ cells are cast and fired in air in nearly the same manner as the MgO. Although also fired on MgO setter plates, the cells are separated from the setters in this case by a $1 / 32-i n$.-thick layer of -60 mesh fused $\mathrm{Al}_{2} \mathrm{O}_{3}$ grain. The setting is fired to $1750^{\circ} \mathrm{C}$ in the same type of kiln and held at peak temperature for $20 \mathrm{~h}$. The fired body has no open porosity, a density of 93 to $94 \%$ of theoretical, and a tired shrinkage of approximately 10-1/2\%.

3. Stirrers (LASL Dwg. No. 26Y-72500).

The stirrers are solid cast rather than drain cast, employing the same casting slip as the cells, and are assembled from three separate components. The shaft, the propellers, and the straightening welght are cast separately and prefired to 1250$1300^{\circ} \mathrm{C}$ in an oxidizing atmosphere. After prefiring, the propellers are cemented in position, and the shaft weight and shaft are grooved and cemented together as indicated in Fig. 4. The MgO casting

*This drawing and all others referenced herein are available from the Clearinghouse for Federal Scientific and Technical Information. 


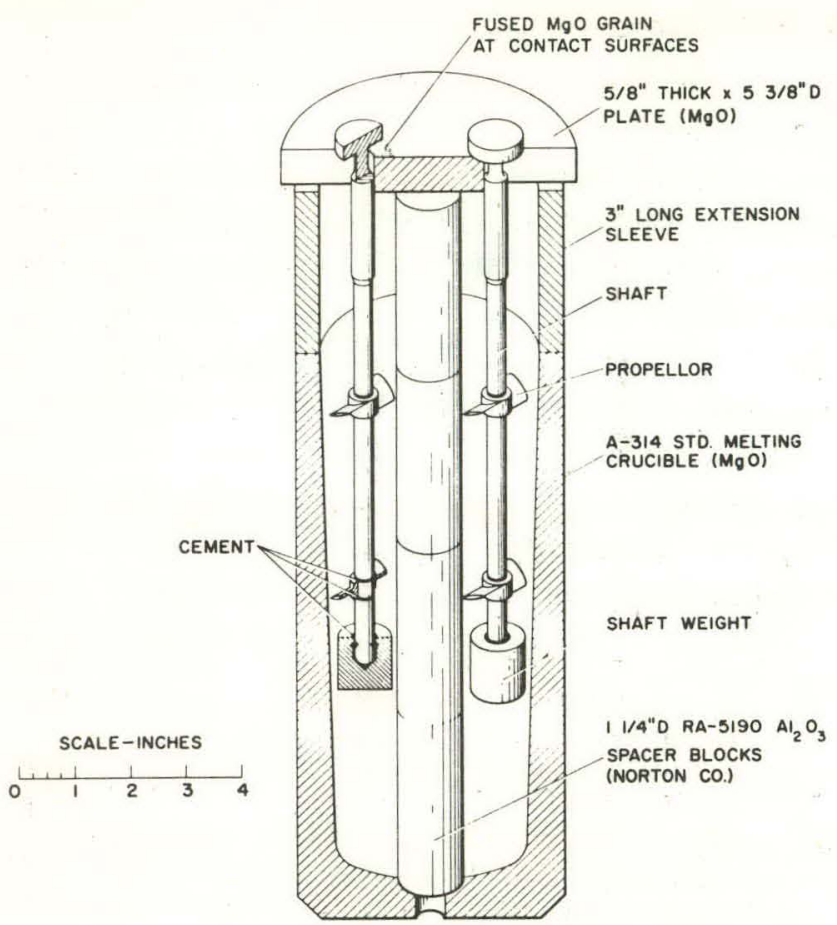

Fig. 4. Setup for firing stirrer assemblies.

slip is employed as the cement for both joints. The cemented assembly is then hung from the flanged end through a notched, coarse-grain MgO plate, separated at the flange-plate interface by a layer of fused $\mathrm{MgO}$ grain as shown in Fig. 4.

This setup is then fired with the same schedule as the refining cells. Following firing and "furnace cooling," the weight and flange are cut off utilizing a conventional cut-off saw and the enlarged shaft section is ground to $0.312-i n$. diam concentric with the balance of the as-cast shaft.

Stirrers of both the $\mathrm{MgO}$ and $\mathrm{Al}_{2} \mathrm{O}_{3}$ compositions have been produced in the manner descrlbed. In cementing the alumina propellers to the shafts, the $\mathrm{Al}_{2} \mathrm{O}_{3}$ slip replaces the MgO slip used for the magnesia assemblies.

4. Anode Sheaths (LASL Dwg. No. 26Y-75970 A-1 and 26Y-72495, Detall 42).

The anode sheaths have been fabricated of the $\mathrm{MgO}$ composition only as it was in full production before the advent of a protective sheath on the anode rod. The slip used for these pieces is different from that described in section $3 \mathrm{~A}$ in that no $\mathrm{MgO}$, only $\mathrm{Y}_{2} \mathrm{O}_{3}$, is added after the $44 \mathrm{~h}$ milling time. The elimination of the coarse fraction increases drying shrinkage and promotes removal from the mold.
The sheaths are drain cast in conventional plaster molds with a flange at the mouth of the mold to facilitate hanging during the firing process (see Flg. 4). As was the case with the stirrers, it was noted at once that the required straightness could be achieved only by hanging the ware. The flange is cut off using a conventional wet-cutting diamond saw after firing.

\section{DISCUSSION}

\section{A. Cementing Slip-Cast Cells}

Although the process described for joining the outer cell and anode chamber created no problem at LASL, it was soon discovered that for other fabricators this was a severe problem. The mode of failure noted in commercially supplied cell assemblies is failure of the bond between the two nested cups. If the as-received cells pass the RF bond test* (as devised by personnel at the Dow Chemical Rocky Flats Plant) wherein a dowel is used as a lever to pry against the inner ccll with an applied load of $3 \mathrm{lb}$, they often fail on initial heatup of the assembly. If the cell does not break loose under this treatment, the bond is satisfactory. Other investigators, in addition to using casting slip for stickup, also evaluated some proprietary commercial cements. These, too, have thus far proved unreliable. It is postulated that the principle reason for the success enjoyed here is the high maturing temperature and the long soaking times routinely utilized. Apparently the body is sufficiently plastic under these maturing conditions to allow the two walls to join together and form an essentially monolithic wall. The reluctance of some coumercial supplicrs to utilize the $\mathrm{Y}_{2} \mathrm{O}_{3}$ addition (because of its relatively high cost) also is felt to contribute to their problems" by lowering the sintering temperature of MgO base bodies. Unlike the HAPO process described by Rosenfels, ${ }^{12}$ the LAMEX process ${ }^{6}$ utilizes a cemented cell, making a reliable joint an absolute necessity.

\section{B. Stirrer Fabrication}

The stirrers used in the refining process must be straight because of their relatively high

*See Detall A, IASI Dwg. No. 26Y-72325, Part 75. 
rotational speed. They must also be free of volds at the juncture of the shaft and stirrer to prevent Pu from entering the voids and wlimately causing fracture because its thermal expansion is greater than that of the MgO.

The presence of volds in the joint is a function of the care and skills employed in that step of the operation. Although this has been reported elsewhere ${ }^{11}$ to have been a problem, no difficulties have been experienced here.

Several techniques were evaluated for setting the stirrer assemblies to minimize warpage during firing. A high degree of success (approximately 95\%) has been reached with the setup 1llustrated in FIg. 4. Others report $60 \%$ 10ss in fabrication of stirrers by the slip casting method.

The welght was found necessary to ensure straightness during firing. The weight of the assembled stirrer itself is insufficient to overcome internal stresses induced during fabrication. Itkewise it was found that reducing the shaft diameter near the brazing collar was beneficial toward this end.

Early in the processing development, slight warpage in the shaft length was obviated by buflding up the last 2 inches of the shaft with oxyacetylene rlame-applied (Metco Type "P" gur*) $v$ and subsequently grinding this bullt-up layer so that it was generally concentric with the major part of the shaft-stirrer assembly. A stirrer embodyling this technique is illustrated in F1g. 1 .

\section{SUMMARY}

Fabrication methods have been developed to produce cclls, sheaths, and stirrers of monolithic, impervious, high purity $\mathrm{Al}_{2} \mathrm{O}_{3}$ and $\mathrm{MgO}$ ceramics to satisfy the rigorous requirements for the electrorefining of Pu.

Although other fabrication methods and compositions have been employed at other installations, the slip-cast magnesia components have been found most sat1sfactory for use at this Laboratory. The cell is used only once, but the stirrers have been used an average of seven cycles, and the sheaths 10 to 12 cycles, without fallure.

FA product of Metelilizing Engineering Company.

\section{REFFERENCES}

1. Kolodney, M., Los Alamos Sclentific Laboratory, Report LA-148, 1944.

2. Leary, J. A.; Benz, R.; Bowersox, D. F.; Bjorkland, C. W.; Johnson, K. W. R.; Maraman, W. J.; Mullins, L. J.; and Reav1s, J. G., Proc. U. N. Intern. Conf. Peaceful Uses At. Energy, 2nd, Geneva, 1958, 17, 376-382 (1958).

3. U.S. Patent No. 2, 923, 670, "Method and Means for Electrolytic Purification of Plutonium," issued July 1963.

4. Mullins, L. J.; Leary, J. A.; Morgan, A. N.; and Maraman, W. Jo, "Plutonium Electrorefining," Ind. Fing. Chem. Process Design Develop., 2, 20-24 (January 1963).

5. U.S. Patent No. 3, 098, 028, "Plutonium Electrorefining Cells," issued July 16, 1963.

6. Mullins, I. J., and Leary, J. A., "Fused Salt Electrorefining of Molten Plutonium and its Alloys by the IAMEX Process," Ind. Eng. Chem. Process Design Develop., 4, 394-400 (October 1965).

7. Leary, J. A., and Mullins, L. J., "Preparation of UItra-High Purity Plutonium," Los Alamos Scientific Laboratory, Report LAMS-3356, 1965.

8. U.S. Patent No. 3, 281, 338, "Method for Producing Ultra High Purity Plutonium Metal," Issued October 25, 1966.

9. Curt18, M. H., and Hopk1ns, H. H., Jr. "Flectrochem. Tech.," 2, No. 7-8,'239-2́44 (1964).

10. Blumenthal, B., and Brodskey, M. B. "Preparation of High Purlty Plutonium," Plutonium 1960, p. 171 , Cleaver-Hume Press, Ltd., London, 1961 .

11. Teter, A. R., "Isostatically Pressed Magnesia Stirrers for Electrorefining Plutonium Metal," Dow Chemical Company, Report RFP-825, 1966.

12. Rosenfels, R. S., "Ceramic Cells and Accessorles for Electrowlnning and Electrorefining of Plutonium Metal," Ceneral Electric HAPO, Report No. RL-SIPP-824, December 17, 1965.

13. Kessel, D. J., et al; Dow Chemical Company Rocky Flats Quarterly Progress Reports for 1965-1966.

14. See References 3, pp. 21-22 and 4, p. 395.

15. Stoddard, S. D., and Allison, A. G., "Casting of Magnesium Oxide in Aqueous Sitps," Am. Ceram. Soc. Bull., 37, No. 9, 409-413 (1958).

16. Stoddard, S. D.; Nuckolls, D. E.; and Cowan, R. E., "Freparation of Pure Impervious Magnesia by Aqueous SIip Casting," Los Alamos Scientific Laboratory, Report LAMS-2639, 1961.

17. Stoddard, S. D.; Cowan, R. E.; and Nuckolls, D. E., "A Slip Casting Process for Calcium Oxide," Am. Ceram. Soc. Bull., 4l, No. 2, 102-104 (1962).

18. Curtis, M. H., "Continuous Electrowinning of Plutonium Metal," HAPO Progress Report, RL-SEP30, Apr1l 1964. See also Reference 9, pp. 2324. 